\title{
Mapping in the Fiskefjord area, southern West Greenland
}

\author{
A. A. Garde and V. R. McGregor
}

Previous geological work on the 1:100 000 map sheet 64 V.1 N (fig. 15) includes published maps of smaller areas by Berthelsen $(1960,1962)$ and Lauerma (1964), mapping by Kryolitselskabet Øresund A/S (Bridgwater et al., 1976) and mapping by GGU geologists for the 1:500000 map sheet Frederikshåb Isblink - Søndre Strømfjord (Allaart et al., 1977, 1978). The Amîtsoq and Nûk gneisses and Malene supracrustal rock units south and east of Godthåbsfjord have not so far been correlated with rocks in the Fiskefjord area. Godthåbsfjord separates the granulite facies gneisses in Nordlandet from amphibolite facies Nûk gneisses on Sadelø and Bjørneøen; the granulite facies metamorphism occurred at about $2850 \mathrm{~m} . y$. (Black et al., 1973), while no published isotopic age determinations from the Fiskefjord area itself are available.

\section{Outer coast of Nordlandet}

During the 1981 field season V. R. M. continued his mapping of the outer coast of Nordlandet. The area now mapped extends from $64^{\circ} 30^{\prime} \mathrm{N}$ to $64^{\circ} 38^{\prime} \mathrm{N}$ and from $52^{\circ} \mathrm{W}$ to $52^{\circ} 15^{\prime} \mathrm{W}$. In addition, an area some $10 \mathrm{~km}$ to the north-east centred on the lake Qorngualik was mapped from a helicopter camp. The extensive coastal outcrops are excellent, but inland the recognition of lithologies is made difficult by very extensive lichen cover and the brownish weathering of all lithologies that retain granulite facies mineral assemblages.

The dominant lithologies are granulite facies gneisses that range form dioritic to trondhjemitic in composition. The gneisses enclose various concentrations of inclusions and some continuous units of older rocks, notably leucogabbro-anorthosite and well-layered basic rocks of probable supracrustal origin. It is possible to delineate major units of gneisses associated with either leucogabbroic lithologies or layered basic rocks. This probably represents an original stratigraphy of alternating units of leucogabbroic rocks and of supracrustal basic rocks that has been split up by the intrusion of the gneisses.

Leucogabbroic rocks are most extensive in a broad, complex synclinorium that plunges gently to SSW. To the west, alternation of gneiss units associated with either leucogabbroic or layered basic lithologies may be the result of an early phase of recumbent isoclinal folding.

Late, discordant bodies of very dark, coarse-grained, plagioclase-rich rocks have been noted in many places, especially associated with basic rocks. They are probably equivalent to the diorites described by Berthelsen (1960) from the Tovqussap nunâ area some $25 \mathrm{~km}$ to the north. Several small occurrences of breccias were found in which closely packed inclusions of various country rock and ultramafic lithologies are separated by small volumes of hornblenditic matrix. Large irregular, discordant bodies of very leucocratic gneisses are the youngest lithologies except for a few late pegmatites and a small number of dolerite dykes.

With the exception of the late pegmatites and dolerite dykes, all the rocks in the area have been affected by granulite facies metamorphism that outlasted the main deformation. On the outer coast most rocks retain granulite facies mineral assemblages. Static retrogression 
to amphibolite facies has been more extensive in the inland area and is virtually complete east of Qorngualik.

\section{The area between Fiskefjord and Narssarssuaq}

The area north and east of Ulamertoq in the north-eastern corner of the map sheet was mapped by A. A. G. in 1981. In this area amphibolites (probably equivalent to the Malene amphibolites) with associated ultramafic rocks, norite, and biotite-hornblende-plagioclase rocks have been intruded by voluminous rocks of tonalitic to trondhjemitic, and rarely granitic, composition (probably equivalent to Nûk gneisses) that now form generally very homogeneous gneisses which make up over 90 per cent of the area. The gneisses were originally intruded in several phases; the earliest phases are richer in plagioclase, biotite and/or hornblende than the later ones. Thin pegmatite sheets of granitic composition are common, and in small areas form several per cent of the exposed rock.

The structure is characterised by steep north-south trending foliation and by upright close to isoclinal folds on a kilometre-scale with south-plunging axes, superimposed on isoclinal folds; later shearing parallel to the general north-south foliation occurs locally. Boundaries between amphibolite and gneiss are often arbitrary, as is commonly found elsewhere in the Archaean basement of southern West Greenland: the amphibolites appear to have been split up by the leucocratic rocks; only the central parts of the thickest amphibolites are devoid of subconcordant gneiss sheets, and up to about $100 \mathrm{~m}$ outside the arbitrary boundaries the gneiss may contain abundant amphibolite inclusions. The amphibolites, in addition to being compositionally banded, are often well-foliated and with decimetre-scale isoclinal folds. In the gneisses, undeformed or little deformed migmatitic structures are often found with pale, coarsely biotite-spotted neosome veins in even-grained, grey to pinkish host gneisses, whereas foliation is generally weak or absent and nebulitic folds are only occasionally visible.

Mineral assemblages generally represent amphibolite facies metamorphic conditions, and the gneisses are correspondingly light coloured. However, orthopyroxene is locally present in mafic rocks, and orthopyroxene relics also occur in a dark-coloured, even-grained, homogeneous tonalitic gneiss, which forms a $700 \mathrm{~m}$ thick unit on the western flank of a synform fold $5 \mathrm{~km}$ east of Ulamertoq. Similar, dark, sometimes orthopyroxene-bearing gneisses are interbanded on a decimetre-scale with pale migmatitic gneiss in other parts of the mapped area. Apparently granulite facies metamorphism was widespread, but the area subsequently suffered retrogressive metamorphism to amphibolite facies under almost static conditions, resulting in the texturally remarkably homogeneous gneisses and development of the migmatites mentioned above. The retrogression often worked selectively on a small scale, and is likely to have been caused by introduction of water rather than by general $P-T$ changes.

\section{References}

Allaart, J. H., Jensen S. B., McGregor, V. R. \& Walton, B. J. 1977: Reconnaissance mapping for the 1:500 000 map sheet in the Godthåb-Isua region, southern West Greenland. Rapp. Grønlands geol. Unders. 85, 50-54.

Allaart, J. H., Friend, C. R. L., Hall, R. P., Jensen, S. B. \& Roberts, I. W. N. 1978: Continued 
1:500000 reconnaissance mapping in the Precambrian of the Sukkertoppen region, southern West Greenland. Rapp. Grønlands geol. Unders. 90, 50-54.

Berthelsen, A. 1960: Structural studies in the pre-Cambrian of western Greenland II. Geology of Tovqussap nunâ. Bull. Grønlands geol. Unders. 25 (also Meddr Grønland 123,1), 223 pp.

Berthelsen, A. 1962: Structural studies in the pre-Cambrian of western Greenland III. Southern Sukkertoppen district. Bull. Grønlands geol. Unders. 31 (also Meddr Grønland 123,2) 46 pp.

Black, L. P., Moorbath, S, Pankhurst, R. J. \& Windley, B. F. 1973: ${ }^{207} \mathrm{~Pb} /{ }^{206} \mathrm{~Pb}$ whole rock age of the Archaean granulite facies metamorphic event in West Greenland. Nature Phys. Sci. 244, 50-53.

Bridgwater, D., Keto, L., McGregor, V. R. \& Myers, J. S. 1976: Archaean gneiss complex of Greenland, In Escher, A. \& Watt, W. S. (edit) Geology of Greenland, 18-75. Copenhagen: Geol. Surv. Greenland.

Lauerma, R. 1964: On the structure and petrography of the Ipernat dome, western Greenland. Bull. Grønlands geol. Unders. 46 (also Bull. Comm. géol. Finlande 251), 88 pp.

V. R. M. Atangmik, 3912 Sukkertoppen, Greenland.

\section{Field work in the Ujaragssuit nunât area, Ivisârtoq region, inner Godthåbsfjord, southern West Greenland}

\section{Brian Chadwick and Martin A. Crewe}

Following the successful completion of the Buksefjorden project, 63 V.1 N (1972-1979), the Geological Survey of Greenland and the Department of Geology, University of Exeter, have begun another joint project in the Ivisârtoq region, $64 \mathrm{~V} .2 \mathrm{~N}$, in inner Godthåbsfjord. The field programmes (1981-1984) and laboratory studies at Exeter are being organised on lines similar to those of the Buksefjorden project, with supervision of four research assistants by B. Chadwick and K. Coe. M. A. Crewe and S. Robertson began work as research assistants in 1981. The generous support by the Survey, the University of Exeter, and the Natural Environment Research Council, UK, is gratefully acknowledged.

During the 1981 field season Chadwick and Crewe worked in Ujaragssuit nunat in the north-east and Coe and Robertson worked in the Kangiussap nunâ area in the west of the Ivisârtoq region. Because of radical differences in the geology of each area, marked especially by the degree of development of Nûk gneisses, the field reports are given as two separate accounts, although they are complementary. The Ivisârtoq region was mapped on a rapid reconnaissance basis in 1976 (Allaart et al., 1977), and results of more detailed studies in certain parts of the region have been presented by Walton (1976), Friend \& Hall (1977), Hall \& Friend (1979) and Hall (1980). 